\title{
Synthesis, crystal structure and characterization of a new Octane-1,8-diammonium bis(dihydrogenmonophosphate)
}

\author{
Mohamed Lahbib Mrad ${ }^{1}$, Salah Ammar ${ }^{2}$, Valeria Ferretti ${ }^{3}$, Mohamed Rzaigui ${ }^{1}$, Cherif Ben Nasr ${ }^{*}$ \\ ${ }^{1}$ Laboratoire de chimie des Matériaux, Faculté des Sciences de Bizerte, Zarzouna, Tunisie; \\ ${ }^{2}$ Faculté des Sciences de Gabes, Tunisie; \\ ${ }^{3}$ Chemistry Department and Centro di Strutturistica Diffrattometrica, University of Ferrara, Ferrara, Italy \\ Email: cherif_bennasr@yahoo.fr, cherif.bennasr@,fsb.rnu.tn
}

Received 7 March 2011; revised 9 April 2011; accepted 12 April 2011.

\begin{abstract}
The synthesis and the structure of a new $\left[\mathrm{H}_{3} \mathrm{~N}-\left(\mathrm{CH}_{2}\right)_{8}\right.$ $\left.-\mathrm{NH}_{3}\right]\left[\mathrm{H}_{2} \mathrm{PO}_{4}\right]_{2}$ is described. This compound crystallizes in the orthorhombic system, with the centric space group Pbon and the following unit cell parameters: $a=7.2887(4), b=9.1728(6), c=23.2169$ (19) $\AA, Z=4$ and $V=1552.23$ (18) $\AA^{3}$. The crystal structure has been solved and refined to $R=0.074$ and $R_{(w)}=0.173$. The $\left[\mathrm{H}_{2} \mathrm{PO}_{4}\right]^{-}$entities are associated by $\mathrm{O}---\mathrm{H}$...O strong hydrogen bonds to form layers. These latters are interconnected with the organic entities via $(\mathrm{N})-\mathrm{H}$...O hydrogen bonds. In this atomic arrangement, $H$ bonds between the different species play an important role in the three-dimensional network. This compound has also been characterized by infrared spectroscopy, solid state MAS-NMR and thermal analysis.
\end{abstract}

Keywords: X-Ray Diffraction; NMR Spectroscopy; IR Spectroscopy; ATG

\section{INTRODUCTION}

Recent years have witnessed an explosion of great interest in hybrid organic-inorganic framework solids not only for their intriguing architectures and topologies, but also for their potential applications in optical, electrical, magnetic, and micro-porous materials [1,2]. In this area the hydrogen bonding is of intense interest because of their widespread occurrence in biological system. So it is very helpful to search simple molecules allowing to understanding the configuration and the function of some complex macromolecules. The hybrid compounds are rich in H-bonds and they could be used to this effect because of their potential importance in constructing sophisticated assemblies from discrete ionic or molecular building blocks due to their strength and directionality $[3,4]$. In this work, the combination of octandiamine and phosphoric acid has been chosen to elaborate the special hydrogen-bond pattern.

\section{EXPERIMENT}

\subsection{Chemical Preparation}

Crystals of the title compound have been prepared in a Petri dish by adding $50 \mathrm{mmol}(3.4 \mathrm{~mL})$ of concentrated orthophosphoric acid (Fluka, 85\%, d = 1.7) to $25 \mathrm{mmol}$ (3.6 g) of octane-1,8-diamine (Acros) dissolved in ethanol. After agitation, the resulting solution has been slowly evaporated at room temperature until the formation of single crystals suitable for X-ray structure analysis and remained stable under normal conditions of temperature and humidity (yield $=64 \%$ ).

\subsection{Investigation Techniques}

The title compound has been studied by various physico-chemical methods: X-ray diffraction, Infrared spectroscopy and Thermal analysis.

\subsubsection{X-Ray Diffraction}

A single crystal was carefully selected under polarizing microscope in order to perform its structural analysis by $\mathrm{X}$-ray diffraction. The intensity data were collected on a Nonius Kappa CCD diffractometer at room temperature using graphite-monochromated $\mathrm{MoK} \alpha$ radiation $(\lambda=$ $0.71073 \AA$ ). The structure was solved by direct methods with the SIR97 program [5] and refined on $\mathrm{F}_{2}$ by fullmatrix least-squares methods with anisotropic non-H atoms using the SHELXL-97 [6] program within WINGX [7]. All the $\mathrm{H}$ atoms were found in the Difference Fourier map and refined isotropically. The drawings were made with Diamond [8]. Crystal data and experimental parameters used for the intensity data collection are summarized in Table 1. 
Table 1. Crystal data, experimental parameters used for the intensity data collection, strategy and final results of the structure determination of $\left[\mathrm{H}_{3} \mathrm{~N}-\left(\mathrm{CH}_{2}\right)_{8}-\mathrm{NH}_{3}\right]\left[\mathrm{H}_{2} \mathrm{PO}_{4}\right]_{2}$.

\begin{tabular}{|c|c|}
\hline \multicolumn{2}{|l|}{ Crystal data } \\
\hline$\left.\underline{2\left(\mathrm{P}_{2}\right.} \underline{\mathrm{H}}_{2} \underline{\mathrm{O}}_{4}\right) \cdot\left(\mathrm{C}_{8} \underline{\mathrm{H}}_{22} \underline{\mathrm{N}_{2}}\right)$ & $F(000)=\underline{728}$ \\
\hline$M_{r}=\underline{340.25}$ & $D_{\mathrm{x}}=\underline{1.456} \mathrm{Mg} \mathrm{m}^{-3}$ \\
\hline Orthorhombic, $\underline{P b c n}$ & Mo $\mathrm{K} \alpha$ radiation \\
\hline$a=\underline{7.2887(4) \AA}$ & $\lambda=\underline{0.71073} \AA$ \\
\hline$b=\underline{9.1728(6) \AA}$ & $\mu=\underline{0.32} \mathrm{~mm}^{-1}$ \\
\hline$c=\underline{23.2169(19) \AA}$ & $\mathrm{T}=\underline{295} \mathrm{~K}$ \\
\hline$V=\underline{1552.23(18)} \AA^{3}$ & Prismatic, colourless \\
\hline$Z=\underline{4}$ & $\underline{0.29} \times \underline{0.25} \times \underline{0.14} \mathrm{~mm}$ \\
\hline \multicolumn{2}{|l|}{ Data collection } \\
\hline Nonius Kappa CCD diffractometer & Rint $=\underline{0.046}$ \\
\hline Radiation source: fine-focus sealed tube & $\theta_{\min }=3.16^{\circ}$ \\
\hline Graphite & $\theta_{\max }=27.10^{\circ}$ \\
\hline$\varphi$ scans and $\omega$ scans & $h=-8.8$ \\
\hline 2437 measured reflections & $k=-11.11$ \\
\hline 1429 independent reflections & $l=-29.29$ \\
\hline \multicolumn{2}{|l|}{ Refinement } \\
\hline $\mathrm{R}\left[\mathrm{F}^{2}>2 \sigma\left(\mathrm{F}^{2}\right)\right]=0.074$ & 50 restraints \\
\hline$w R\left(F^{2}\right)=0.173$ & $\underline{\text { All H-atom parameters refined }}$ \\
\hline $\mathrm{S}=1.29$ & $(\Delta / \sigma)_{\max }=\underline{0.001}$ \\
\hline 1429 reflections & $\Delta \rho_{\max }=0.34 \mathrm{e} \AA^{-3}$ \\
\hline 143 parameters & $\Delta \rho_{\min }=-0.37 \mathrm{e} \AA^{-3}$ \\
\hline
\end{tabular}

\subsubsection{NMR Spectroscopy}

All NMR spectra were recorded on a solid-state high-resolution Bruker DSX-300 spectrometer operating at $75.49 \mathrm{MHz}$ for ${ }^{13} \mathrm{C}$ and $121.51 \mathrm{MHz}$ for ${ }^{31} \mathrm{P}$, with a classical $4 \mathrm{~mm}$ probehead allowing spinning rates up to $10 \mathrm{kHz} .{ }^{13} \mathrm{C}$ chemical shifts are given relative to tetramethylsilane and ${ }^{31} \mathrm{P}$ ones are relative to $85 \% \mathrm{H}_{3} \mathrm{PO}_{4}$ (external references, precision $0.5 \mathrm{ppm}$ ). Phosphorus spectrum was recorded under classical MAS conditions while the carbon ones were recorded by the use of cross-polarization (CP) from protons (contact time $5 \mathrm{~ms}$ ) and MAS. In all cases, it was checked that there was a sufficient delay between the scans allowing a full relaxation of the nuclei.

\subsubsection{IR Spectroscopy}

Spectrum was recorded in the range $4000-400 \mathrm{~cm}^{-1}$ with a "Perkin-Elmer FTIR" spectrophotometer 1000 using a sample dispersed in spectroscopically pure $\mathrm{KBr}$ pellet.

\subsubsection{Thermal Analysis}

Thermal analysis was performed using a multimodule 92 Setaram analyzer operating from room temperature up to $500^{\circ} \mathrm{C}$ at an average heating rate of $5^{\circ} \mathrm{C} \cdot \mathrm{min}^{-1}$.

\section{RESULTS AND DISCUSSION}

\subsection{X-Ray Diffraction}

The asymmetric unit of $\left[\mathrm{H}_{3} \mathrm{~N}-\left(\mathrm{CH}_{2}\right)_{8}-\mathrm{NH}_{3}\right]\left[\mathrm{H}_{2} \mathrm{PO}_{4}\right]_{2}$ is built by a $\mathrm{H}_{2} \mathrm{PO}_{4}^{-}$anion and a the half of octane diammonium cation. Figure 1 shows an ORTEP [9] plot of the structure including the atom labels and their vibrational ellipsoids at $40 \%$ probability. The atomic arrange- 


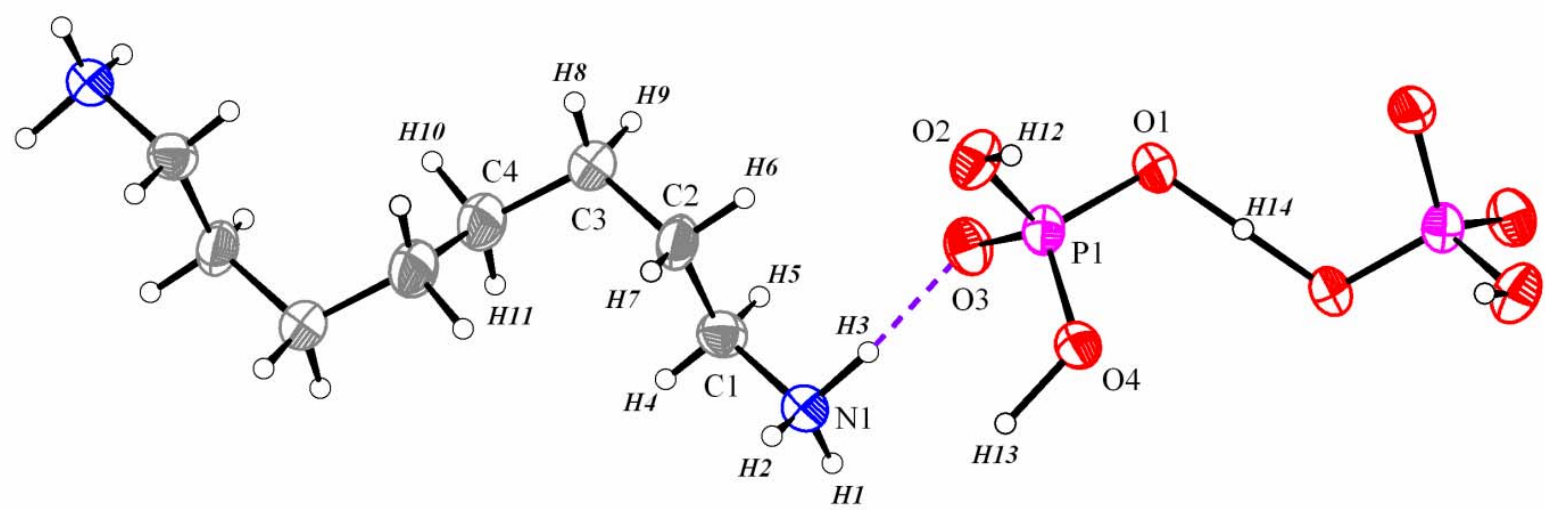

Figure 1. Asymmetric unit of $\left[\mathrm{H}_{3} \mathrm{~N}-\left(\mathrm{CH}_{2}\right)_{8}-\mathrm{NH}_{3}\right]\left[\mathrm{H}_{2} \mathrm{PO}_{4}\right]_{2}$ with atom labels and $40 \%$ probability displacement ellipsoids for non-H atoms. Symmetry codes: (i) $-\mathrm{x}+2,-\mathrm{y},-\mathrm{z}$; (ii) $-\mathrm{x}+1, \mathrm{y},-\mathrm{z}+1 / 2$.

ment of $\left[\mathrm{H}_{3} \mathrm{~N}-\left(\mathrm{CH}_{2}\right)_{8}-\mathrm{NH}_{3}\right]\left[\mathrm{H}_{2} \mathrm{PO}_{4}\right]_{2}$ can be described by inorganic layers of $\mathrm{H}_{2} \mathrm{PO}_{4}{ }^{-}$anions located in $(\mathrm{a}, \mathrm{b})$ planes (Figure 2). Between these layers, which are located at $\mathrm{z}$ $=(2 \mathrm{n}+1) / 4$, are anchored organic cations through $\mathrm{N}-\mathrm{H} . . . \mathrm{O}$ hydrogen bonds (Figure 3 ). The detailed geometry of $\mathrm{H}_{2} \mathrm{PO}_{4}^{-}$groups (Table 2) shows that the $\mathrm{P}-\mathrm{O}$ bond is significantly shorter (1.501(4) $\AA$ ) than the $\mathrm{P}-\mathrm{OH}$ bonds varying between $1.530(4)$ and $1.555(4) \AA$. This is in agreement with the data relative to the protonated oxoanions [10]. However, the O...O distances involved in the hydrogen bonds $(2.505-2.595 \AA)$ are of the same order of magnitude of the $\mathrm{O}-\mathrm{O}$ in the $\mathrm{PO}_{4}$ tetrahedron (2.432 - $2.531 \AA)$, this should allow us to consider the $\left[\mathrm{H}_{2} \mathrm{PO}_{4}\right]_{n}^{\mathrm{n}}$ - subnetwork as a polyanion. The O-P-O angles spread from $106.2(2)^{\circ}$ to $114.2(2)^{\circ}$. This distortion from the tetrahedral value has been regularly noted in other organic phosphates [11]. All these geometrical parameters are in full agreement with those observed in such anions in other organic dihydrogenomonophosphates [12]. Moreover, it is worth noting that two hydrogen atoms belonging to the phosphate ion have 0.5 occupancy and are shared between two molecules. This explains the long O-H lengths for O1-H14 (1.28(2) $\AA$ and O4-H13 (1.254(6) $\AA$ ).

The diammonium octane chain lies across a crystallographic inversion centre and hence the asymmetric unit contains one dihydrogenomonophosphate anion and one-half of the octane diammonium cation. The hydrocarbon chain is also not extended as is common in long chained hydrocarbons but shows significant folding and deviation from planarity. This is clearly evident from the torsion angle along the $\mathrm{N} 1-\mathrm{C} 1-\mathrm{C} 2-\mathrm{C} 3$ bond $\left[-179.6^{\circ}\right]$, along the $\mathrm{C} 1-\mathrm{C} 2-\mathrm{C} 3-\mathrm{C} 4$ bond $\left(66.3^{\circ}\right)$ and along the $\mathrm{C} 2-\mathrm{C} 3-\mathrm{C} 4-\mathrm{C} 4^{\mathrm{i}}\left(61.6^{\circ}\right)$. An intricate three-dimensional hydrogen-bonding network exists in the crystal structure, with each $\mathrm{H}$ atom on the ammonium group exhibiting interaction to the $\mathrm{H}_{2} \mathrm{PO}_{4}^{-}$anion.

\subsection{NMR Spectroscopy}

Proton decoupled ${ }^{31} \mathrm{P}$ MAS-NMR spectrum of crystalline dihydrogenmonophpsphate $\left[\mathrm{H}_{3} \mathrm{~N}-\left(\mathrm{CH}_{2}\right)_{8}-\mathrm{NH}_{3}\right]\left[\mathrm{H}_{2} \mathrm{PO}_{4}\right]_{2}$ is given in Figure 4. It exhibits two resonance peaks at $0.03 \mathrm{ppm}$ and $1.73 \mathrm{ppm}$ with two corresponding satellite spinning side bands at equal intervals (spinning rate of the sample expressed in ppm). These chemical shift values agree well with those of monophosphates, between $-10 \mathrm{ppm}$ and $+5 \mathrm{ppm}$ depending on the compound [13-18]. However, the asymmetric unit contains only one crystallographic site. This anomaly can be explained by the fact that the dihydrogenmonophosphate group moves between two close positions with a frequency that we observed these positions in NMR, while in X-ray only a mean position was detected.

The ${ }^{13} \mathrm{C}$ CP-MAS NMR spectrum of the title compound displays four resonance different signals (Figure 5). This spectrum is in good agreement with the X-ray structure, which shows four crystallographically unequivalent carbon sites. The carbon atoms of the organic group are depicted in Figure 1.

To assign NMR components to different carbon atoms, we used the ACDlabs software. The chemical shifts of the four carbon atoms were calculated and the results are regrouped in Table 5. The obvious difference between the theoretical and the experimental chemical shift values observed for the $\mathrm{C} 1$ carbon atom is attributed to the fact that this later is directly bonded to the ammonium group which is involved in hydrogen bonds with the dihydrogenmonophosphate anion.

\subsection{IR Spectroscopy}

The infrared spectrum of crystalline $\left[\mathrm{H}_{3} \mathrm{~N}-\left(\mathrm{CH}_{2}\right)_{8-}\right.$ $\left.\mathrm{NH}_{3}\right]\left[\mathrm{H}_{2} \mathrm{PO}_{4}\right]_{2}$ is shown in Figure 6. To assign the IR peaks to the vibrational modes, we examined the modes and frequencies observed in similar compounds [19].

- Frequencies in the range $3600 \mathrm{~cm}^{-1}$ and $2300 \mathrm{~cm}^{-1}$ 
Table 2. Main interatomic distances $(\mathrm{A})$ and bond angles $\left(^{\circ}\right)$ in the $\mathrm{PO}_{4}$ tetrahedron and octane-1,8-diammonium group.

\begin{tabular}{llll}
\hline $\mathrm{P} 1-\mathrm{O} 3$ & $1.501(4)$ & $\mathrm{C} 2-\mathrm{C} 3$ & $1.522(8)$ \\
\hline $\mathrm{P} 1-\mathrm{O} 4$ & $1.552(4)$ & $\mathrm{C} 4-\mathrm{C} 4$ & $1.517(12)$ \\
$\mathrm{P} 1-\mathrm{O} 2$ & $1.555(4)$ & & \\
$\mathrm{P} 1-\mathrm{O} 1$ & $1.530(4)$ & & \\
$\mathrm{N} 1-\mathrm{C} 1$ & $1.483(6)$ & & \\
$\mathrm{C} 1-\mathrm{C} 2$ & $1.509(7)$ & $\mathrm{N} 1-\mathrm{C} 1-\mathrm{C} 2$ & $111.5(4)$ \\
$\mathrm{O} 3-\mathrm{P} 1-\mathrm{O} 4$ & $111.7(2)$ & $\mathrm{C} 1-\mathrm{C} 2-\mathrm{C} 3$ & $112.8(5)$ \\
$\mathrm{O} 3-\mathrm{P} 1-\mathrm{O} 2$ & $107.3(2)$ & $\mathrm{C} 4-\mathrm{C} 3-\mathrm{C} 2$ & $115.3(6)$ \\
$\mathrm{O} 4-\mathrm{P} 1-\mathrm{O} 2$ & $109.1(2)$ & $\mathrm{C} 3-\mathrm{C} 4-\mathrm{C} 4$ & $114.6(7)$ \\
$\mathrm{O} 3-\mathrm{P} 1-\mathrm{O} 1$ & $114.1(2)$ & & \\
$\mathrm{O} 4-\mathrm{P} 1-\mathrm{O} 1$ & $106.2(2)$ & & \\
$\mathrm{O} 2-\mathrm{P} 1-\mathrm{O} 1$ & $108.3(2)$ & & \\
\hline Symmetry code: (i) $-\mathrm{x}+2,-\mathrm{y},-\mathrm{z}$. &
\end{tabular}

Table 3. Hydrogen-bond geometry $\left(\AA,^{\circ}\right)$ in $\left[\mathrm{H}_{3} \mathrm{~N}-\left(\mathrm{CH}_{2}\right)_{8}-\mathrm{NH}_{3}\right]\left[\mathrm{H}_{2} \mathrm{PO}_{4}\right]_{2}$.

\begin{tabular}{|c|c|c|c|c|}
\hline D-H...A & D-H (Å) & H...A ( $(\AA)$ & D-A (Å) & D-H...A ( $\left(^{\circ}\right)$ \\
\hline $\mathrm{N} 1-\mathrm{H} 2 \ldots \mathrm{O} 1$ & 0.84 & 2.20 & $2.973(4)$ & 160 \\
\hline N1-H1_..O4 & 0.913 & 1.935 & $2.817(4)$ & 162 \\
\hline N1-H3...O3 & 1.028 & 1.758 & $2.784(4)$ & 175 \\
\hline $\mathrm{O} 2-\mathrm{H} 11 \ldots \mathrm{O} 3$ & 0.879 & 1.716 & $2.595(4)$ & 177 \\
\hline O1-H14_..O1 & 1.277 & 1.277 & $2.537(4)$ & 167 \\
\hline O4-H13...O4 & 1.254 & 1.254 & $2.505(4)$ & 175 \\
\hline
\end{tabular}

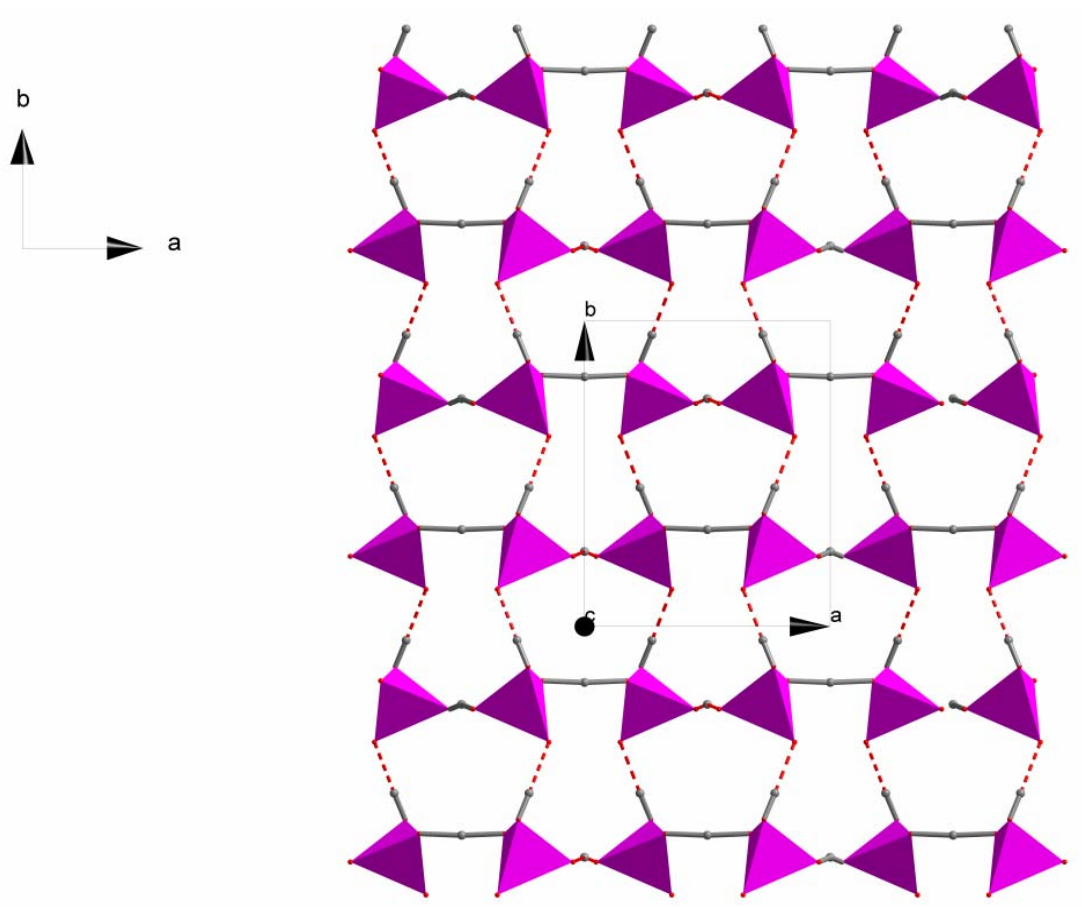

Figure 2. Projection along the $\mathrm{c}$-axis at $\mathrm{z}=1 / 4$ of the inorganic layer in $\left[\mathrm{H}_{3} \mathrm{~N}-\left(\mathrm{CH}_{2}\right)_{8}-\mathrm{NH}_{3}\right]\left[\mathrm{H}_{2} \mathrm{PO}_{4}\right]_{2}$ structure. $\mathrm{H}_{2} \mathrm{PO}_{4}$ is given in polyhedral representation. Hydrogen bonds are denoted by dotted lines. 


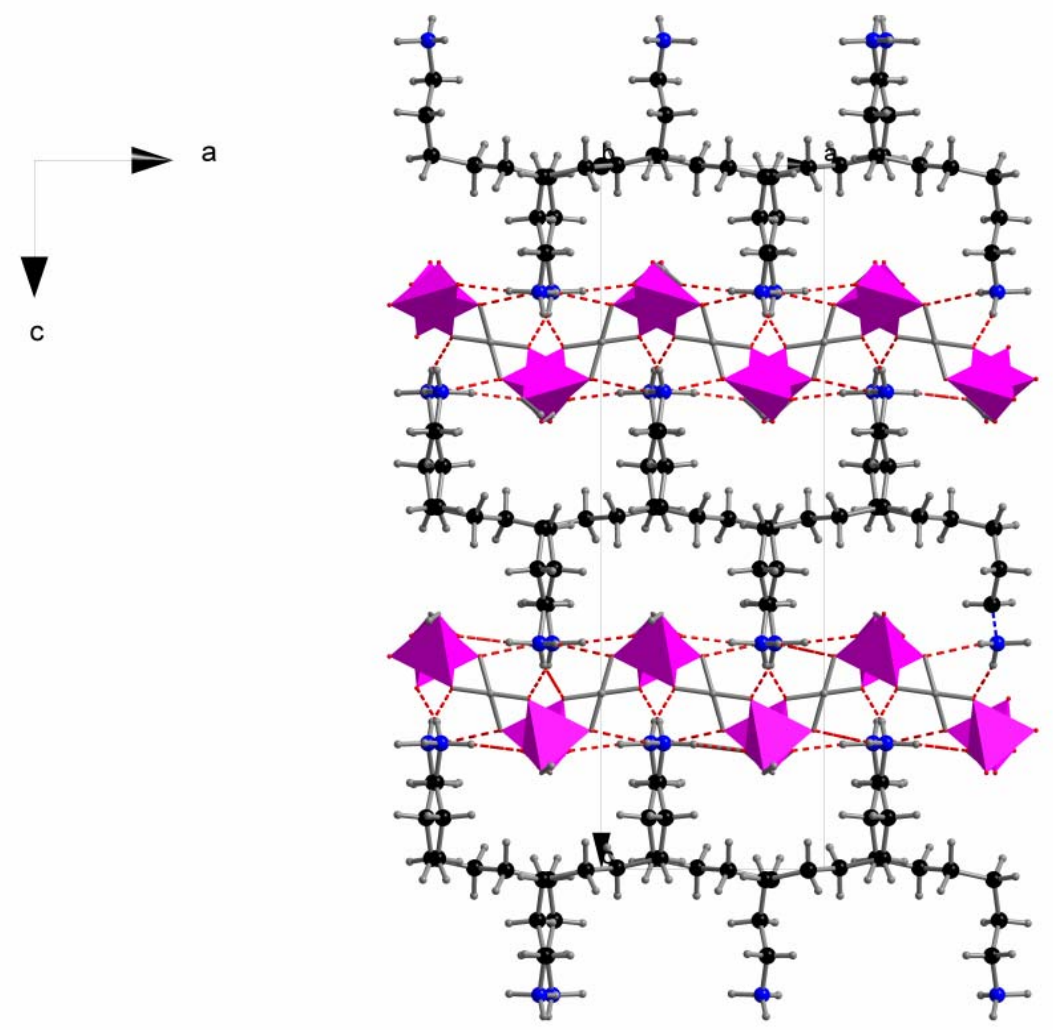

Figure 3. Projection of the structure of $\left[\mathrm{H}_{3} \mathrm{~N}-\left(\mathrm{CH}_{2}\right)_{8}-\mathrm{NH}_{3}\right]\left[\mathrm{H}_{2} \mathrm{PO}_{4}\right]_{2}$ along the b-axis. $\mathrm{H}_{2} \mathrm{PO}_{4}$ is given in polyhedral representation. Hydrogen bonds are denoted by dotted lines.

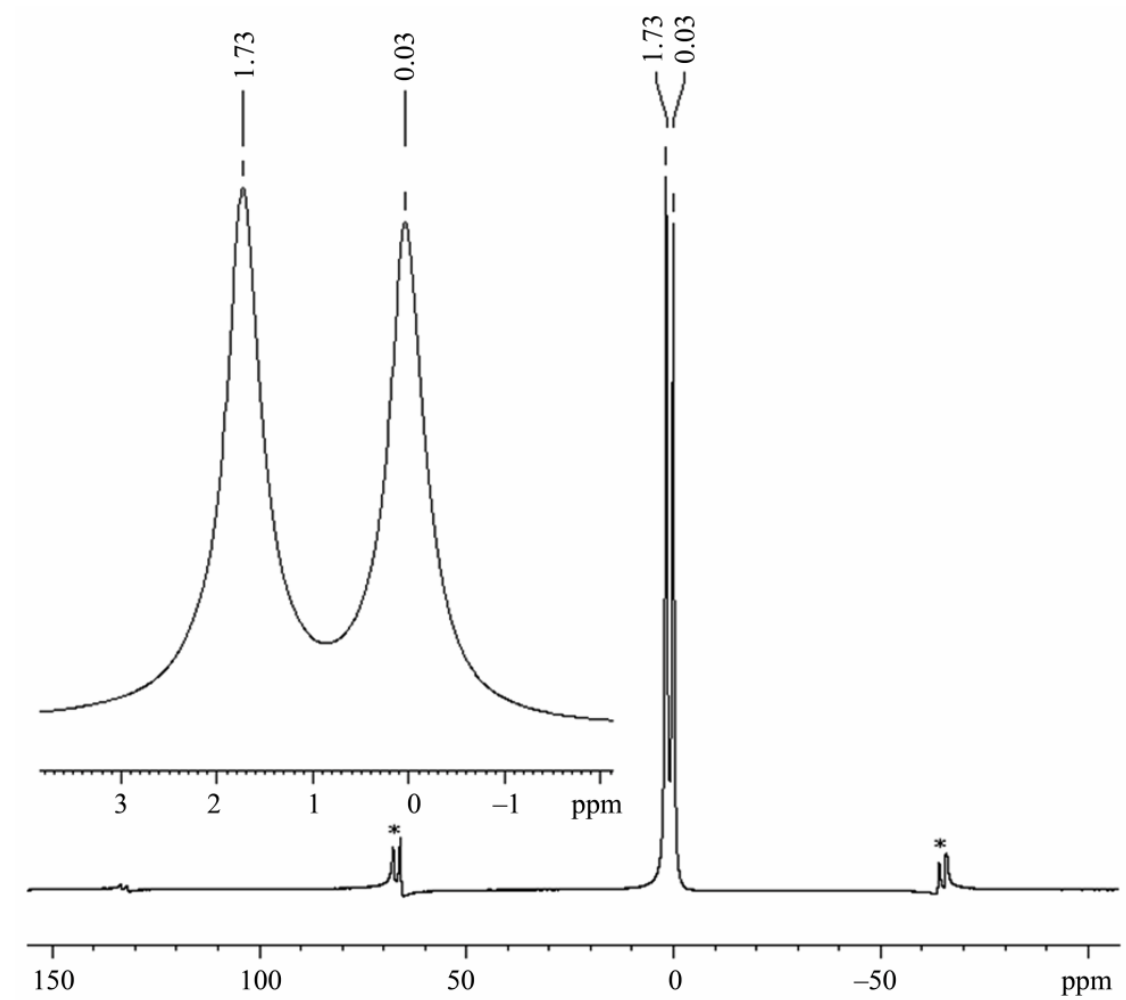

Figure 4. Solid-state ${ }^{31} \mathrm{P}$ MAS NMR spectrum of $\left[\mathrm{H}_{3} \mathrm{~N}-\left(\mathrm{CH}_{2}\right)_{8}-\mathrm{NH}_{3}\right]\left[\mathrm{H}_{2} \mathrm{PO}_{4}\right]_{2}$. ${ }^{*}$ Spinning side bands. 


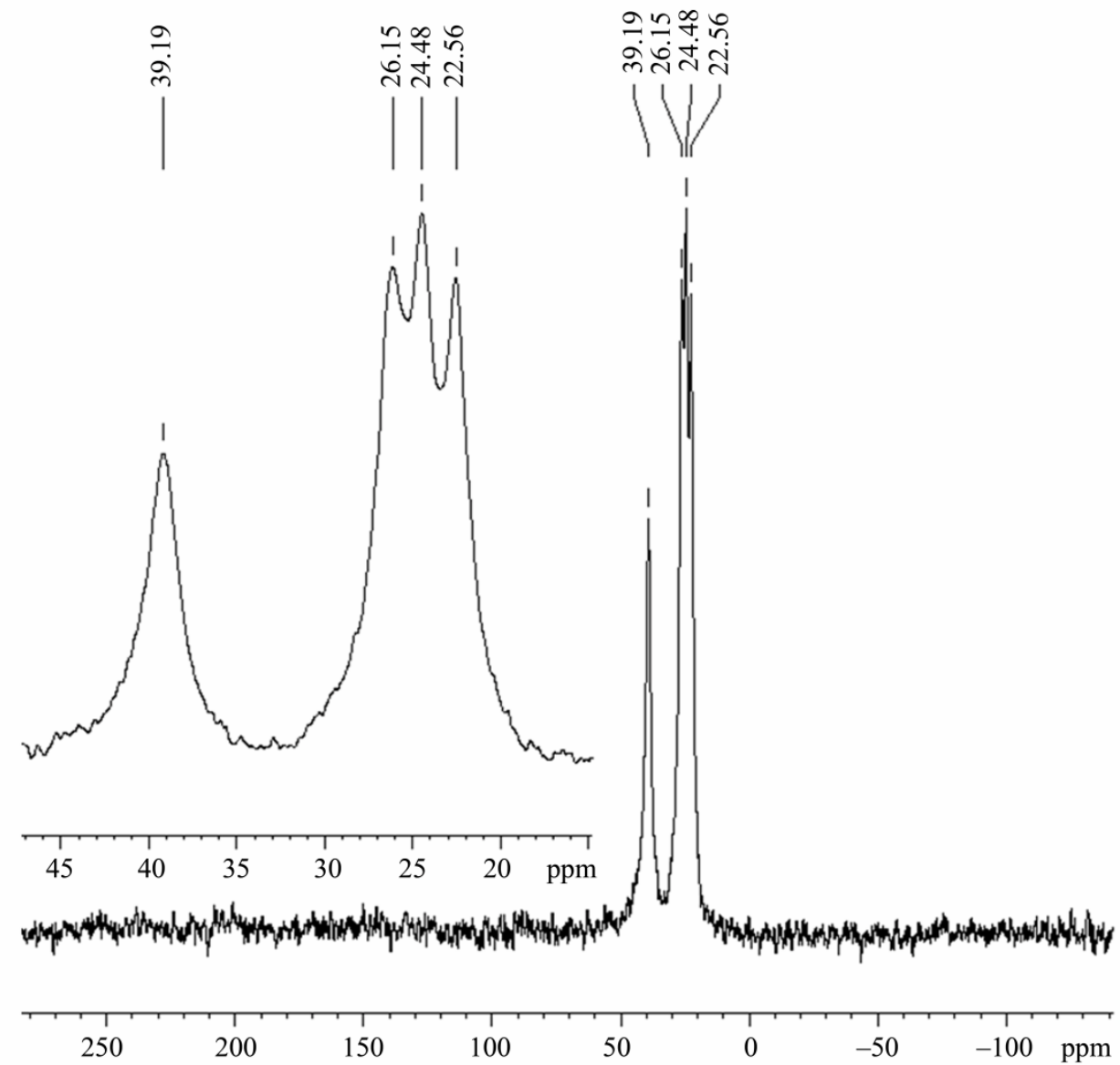

Figure 5. Solid-state ${ }^{13} \mathrm{C}$ CP-MAS NMR spectrum of $\left[\mathrm{H}_{3} \mathrm{~N}-\left(\mathrm{CH}_{2}\right)_{8}-\mathrm{NH}_{3}\right]\left[\mathrm{H}_{2} \mathrm{PO}_{4}\right]_{2}$.

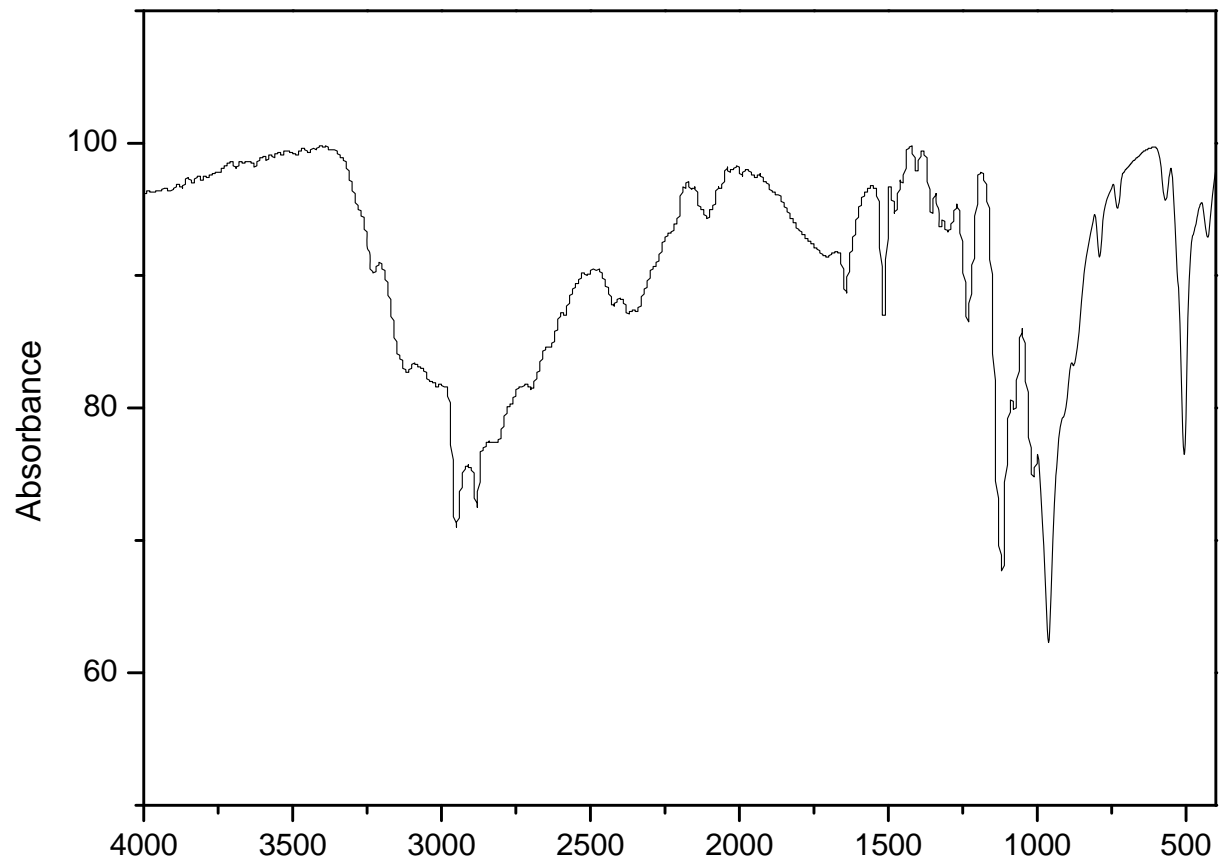

Figure 6. IR absorption spectrum of $\left[\mathrm{H}_{3} \mathrm{~N}-\left(\mathrm{CH}_{2}\right)_{8}-\mathrm{NH}_{3}\right]\left[\mathrm{H}_{2} \mathrm{PO}_{4}\right]_{2}$. 
Table 4. Calculated $\left(\delta_{\text {iso }}\right)$ and experimental $\left(\delta_{\text {exp }}\right)$ chemical shifts of the carbon atoms in $\left[\mathrm{H}_{3} \mathrm{~N}-\left(\mathrm{CH}_{2}\right)_{8}-\mathrm{NH}_{3}\right]\left[\mathrm{H}_{2} \mathrm{PO}_{4}\right]_{2}$.

\begin{tabular}{lcccc}
\hline atoms & $\mathrm{C} 1$ & $\mathrm{C} 2$ & $\mathrm{C} 3$ & $\mathrm{C} 4$ \\
\hline$\delta_{\text {iso }}(\mathrm{ppm})$ & 30.84 & 27.77 & 24.53 & 25.79 \\
$\delta_{\exp }(\mathrm{ppm})$ & 39.19 & 26.15 & 22.56 & 24.48 \\
\hline
\end{tabular}

are attributed to the stretching modes of the organic entity and the hydroxyl of $\mathrm{P}-\mathrm{OH}$ groups $(\mathrm{N}-\mathrm{H}, \mathrm{C}-\mathrm{H}$ and $\mathrm{O}-\mathrm{H})$.

The vibrations between 1650 and $1200 \mathrm{~cm}^{-1}$ are assigned to bending modes $\left(\mathrm{NH}_{3}^{+}\right.$and $\left.\mathrm{CH}_{2}\right)$.

- Bands between $1200-800 \mathrm{~cm}^{-1}$ corresponds to the asymmetric and symmetric $\mathrm{PO}_{4}$ stretching modes [20].

- Frequencies in the domain 650 and $400 \mathrm{~cm}^{-1}$ are attributed to the asymmetric and symmetric $\mathrm{PO}_{4}$ bending modes [21].

\subsection{Thermal Analysis}

The two curves corresponding to the DTA and TGA analysis in argon of $\left[\mathrm{H}_{3} \mathrm{~N}-\left(\mathrm{CH}_{2}\right)_{8}-\mathrm{NH}_{3}\right]\left[\mathrm{H}_{2} \mathrm{PO}_{4}\right]_{2}$ are given in Figure 7. The DTA curve shows that this compound undertakes a series of endothermic peaks in a wide temperature range $\left(180^{\circ} \mathrm{C}-500^{\circ} \mathrm{C}\right)$. The most important one appears at about $186^{\circ} \mathrm{C}$. It corresponds to a melting point, which is in good agreement with the result obtained by the capillarity tube method. From $190^{\circ} \mathrm{C}$, the DTA curve shows a series of weak endothermic peaks characterized by an important weight loss observed on the TGA curve. This thermal phenomenon is attributed to the degradation of the organic entity, well confirmed by the consistent residue of polyphosphoric acid and black carbon obtained at the end of the experiment.

The DSC thermogramme (Figure 8) is particularly characterized by one endothermic peak at about $181^{\circ} \mathrm{C}$ related to the melting compound. The corresponding melting enthalpy is $\mathrm{H}=38.706 \mathrm{KJ} \cdot \mathrm{mol}^{-1}$.

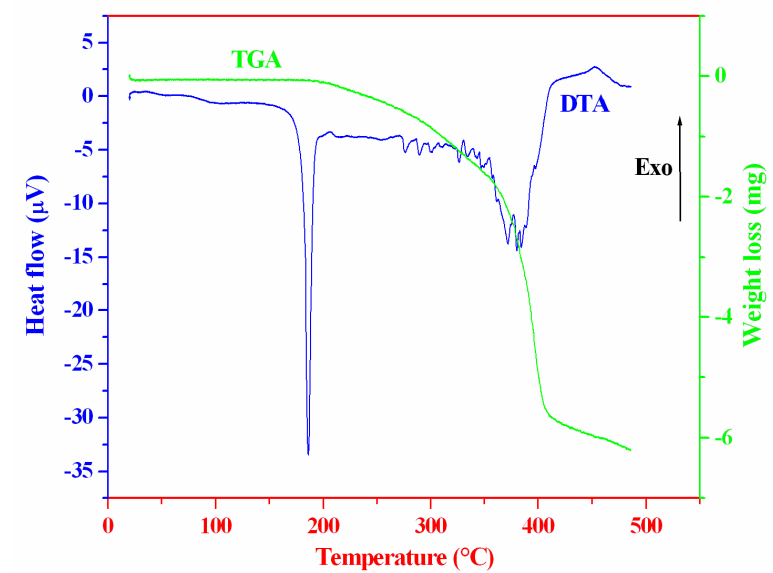

Figure 7. DTA and TGA curves of $\left[\mathrm{H}_{3} \mathrm{~N}-\left(\mathrm{CH}_{2}\right)_{8}-\mathrm{NH}_{3}\right]\left[\mathrm{H}_{2} \mathrm{PO}_{4}\right]_{2}$ at rising temperature.

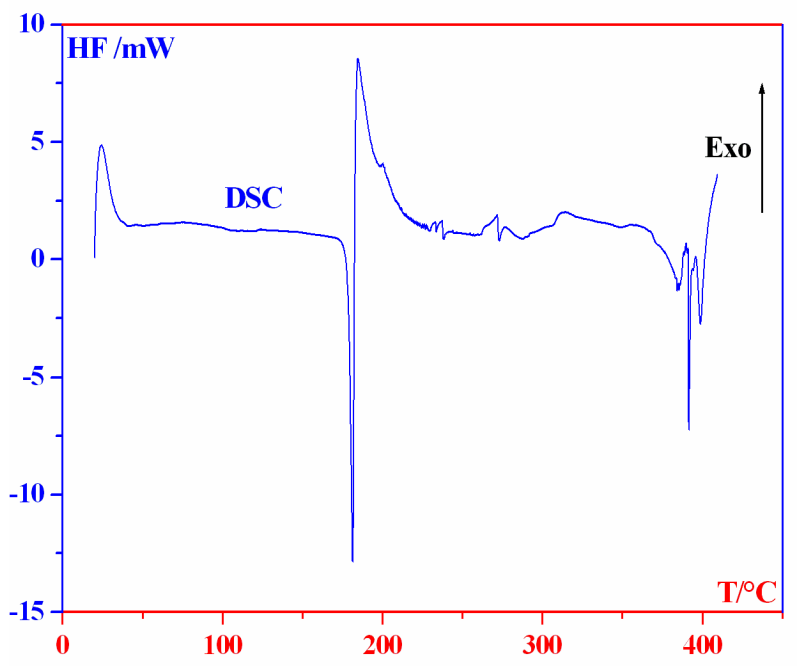

Figure 8. DSC curve of $[\mathrm{H} 3 \mathrm{~N}-(\mathrm{CH} 2) 8-\mathrm{NH} 3][\mathrm{H} 2 \mathrm{PO} 4] 2$ at rising temperature.

\subsection{Supplementary Material}

Crystallographic data for the title compound have been deposited at the Cambridge Crystallographic Data Center as supplementary publication (CCDC-820777). These data can be obtained free of charge at www.ccdc.cam. ac.uk/conts/retrieving.html or from the Cambridge Crystallographic Data Center, 12, Union Road, Cambridge CB2 1EZ, UK; fax: +44 1223/336 033; mailto: deposit@ ccdc.cam.ac.uk).

\section{REFERENCES}

[1] Evans, O.R. and Lin, W.B. (2002) Crystal engineering of NLO materials based on metal-organic coordination networks. Accounts of Chemical Research, 35, 511-522. doi:10.1021/ar0001012

[2] Zhang, J.P. and Chen, X.M. (2006) Crystal engineering of binary metal imidazolate and triazolate frameworks. Chemical Communications, 2006, 1689-1699. doi: $10.1039 / \mathrm{b} 516367 \mathrm{f}$

[3] Steiner, T. (2002) The hydrogen bond in the solid state. Angewandte Chemie International Edition, 41, 48-76. doi:10.1002/1521-3773(20020104)41:1<48::AID-ANIE4 8>3.0.CO;2-U

[4] Jayaraman, K., Choudhury, A. and Rao, C.N.R. (2002) Sulfates of organic diamines: Hydrogen-bonded structures and properties. Solid State Sciences, 4, 413-422. doi:10.1016/S1293-2558(02)01269-4

[5] Altomare, A., Burla, M.C., Camalli, M., Cascarano, G.L., Giacovazzo, C., Guagliardi, A., Moliterni, A.G.G., Polidori, G. and Spagna, R. (1999) SIR97: A new tool for crystal structure determination and refinement. Journal of Applied Crystallography, 32, 115-119. doi:10.1107/S0021889898007717

[6] Sheldrick, G.M. (1997) SHELXL-97, program for crystal structure refinement, University of Göttingen, Göttingen, 
Germany.

[7] Farrugia, L.J. (1999) WinGX suite for small-molecule single-crystal crystallography. Journal of Applied Crystallography, 32, 837-838.

doi:10.1107/S0021889899006020

[8] Brandenburg, K. (1998) Diamond Version 2.0 Impact GbR, Bonn, Germany.

[9] Burnett, M.N. and Johnson C.K. (1996) ORTEPIII. Report ORNL-6895, Oak Ridge National Laboratory, Oak Ridge, Tennessee, USA.

[10] Herzfeld, J. and Berger, A.E. (1980) Sideband intensities in NMR spectra of samples spinning at the magic angle. Journal of Chemical Physics, 73, 6021-6030.

[11] Mrad, M.L., Ben Nasr, C. and Rzaigui, M. (2006) Synthesis and characterization of a new p-phenylenediammonium dihydrogenmonophosphate [p- $\left.\mathrm{NH}_{3} \mathrm{C}_{6} \mathrm{H}_{4} \mathrm{NH}_{3}\right]\left[\mathrm{H}_{2} \mathrm{PO}_{4}\right]_{2}$. Materials Research Bulletin, 41, 1287-1294. doi:10.1016/j.materresbull.2006.01.002

[12] Oueslati, A. and Ben Nasr, C. (2006) Synthesis and crystal structure of a new organic 2-amino-5-chloro pyridinium dihydrogenmonophosphate: $\left(2-\mathrm{NH}_{2}-5-\mathrm{Cl}-\mathrm{C}_{5} \mathrm{H}_{3} \mathrm{NH}\right)$ $\mathrm{H}_{2} \mathrm{PO}_{4}$. Analytical Sciences: X-ray Structure Analysis Online, 22, 225-226.

[13] Hartmann, P., Vogel, J. and Schnabel, B. (1994) The influence of short-range geometry on the ${ }^{31} \mathrm{P}$ chemicalshift tensor in protonated phosphates. Journal of Magnetic Resonance, Series A, 111, 110-114. doi:10.1006/jmra.1994.1234

[14] Kaabi, K., Rayes, A., Ben Nasr, C., Rzaigui, M. and Lefebvre, F. (2003) Synthesis and crystal sructure of a new dihydrogenomonophosphate $\left(4-\mathrm{C}_{2} \mathrm{H}_{5} \mathrm{C}_{6} \mathrm{H}_{4} \mathrm{NH}_{3}\right)$ $\mathrm{H}_{2} \mathrm{PO}_{4}$. Materials Research Bulletin, 38, 741-747. doi:10.1016/S0025-5408(03)00072-2

[15] Oueslati, A., Touati, A., Ben Nasr, C. and Lefebvre, F. (2006) The synthesis and characterization of 2-amino-3methylpyridinium dihydrogenmonophosphate: $\left(\mathrm{C}_{6} \mathrm{H}_{9} \mathrm{~N}_{2}\right)$ -
$\mathrm{H}_{2} \mathrm{PO}_{4}$. Phosphorus, Sulfur, and Silicon and the Related Elements, 181, 2117-2133. doi:10.1080/10426500600614196

[16] Kefi, R., Rayes, A., Ben Nasr, C. and Rzaigui, M. (2006) Synthesis and characterization of a new monophosphate (5-Cl-2,4- $\left.\left(\mathrm{OCH}_{3}\right)_{2} \mathrm{C}_{6} \mathrm{H}_{2} \mathrm{NH}_{3}\right) \mathrm{H}_{2} \mathrm{PO}_{4}$. Materials Research Bulletin, 42, 404-412.

doi:10.1016/j.materresbull.2006.07.007

[17] Oueslati, J., Oueslati, A., Ben Nasr, C. and Lefebvre, F. (2006) Synthesis and crystal structure of a new adduct of dihydrogenphosphate phosphoric acid monohydrate with 8-aminoquinolinium $\left(8-\mathrm{NH}_{2} \mathrm{C}_{9} \mathrm{H}_{6} \mathrm{NH}\right)_{2}\left(\mathrm{H}_{2} \mathrm{PO}_{4}\right)_{2} \mathrm{H}_{3} \mathrm{PO}_{4} \cdot \mathrm{H}_{2} \mathrm{O}$. Solid State Sciences, 8, 1067-1073. doi:10.1016/j.solidstatesciences.2006.03.005

[18] Kefi, R., Ben Nasr, C. and Lefebvre, F. (2007) Synthesis and characterization of a layered chlorozincophosphate templated by protonated 4-methylpiperidine. Crystal Research and Technology, 42, 333-341. doi:10.1002/crat.200610824

[19] Naili, H., Mhiri, T. and Daoud, A. (2001) Structural, vibrational and calorimetric study of a new ammonium dihydrogen phosphate-arsenate: $\mathrm{NH}_{4} \mathrm{H}_{2}\left(\mathrm{PO}_{4}\right)_{0.52}\left(\mathrm{AsO}_{4}\right)_{0.48}$. International Journal of Inorganic Materials, 3, 393-400. doi:10.1016/S1466-6049(01)00022-8

[20] Nemec, I., Cisarova, I. and Micka, Z.J. (1998) Study of the family of glycine-selenious acid addition compounds: crystal structure of diglycine hydrogen selenite and vibrational spectra and DSC measurement of diglycine hydrogen selenite and monoglycine-selenious acid crystals. Journal of Solid State Chemistry, 140, 71-82. doi:10.1006/jssc. 1998.7855

[21] Haile, S.M., Calkins, P.M. and Boysen, D. (1998) Structure and vibrational spectrum of $\beta-\mathrm{Cs}_{3}\left(\mathrm{HSO}_{4}\right)_{2}\left[\mathrm{H}_{2-\mathrm{x}}\left(\mathrm{P}_{1-\mathrm{x}}\right.\right.$, $\left.\mathrm{S}_{\mathrm{x}}\right)_{4}$ ] $(\mathrm{x} \sim 0.5)$, a new superprotonic conductor, and a comparison with $\alpha-\mathrm{Cs}_{3}\left(\mathrm{HSO}_{4}\right)_{2}\left(\mathrm{H}_{2} \mathrm{PO}_{4}\right)$. Journal of Solid State Chemistry, 139, 373-387. doi:10.1006/jssc.1998.7861 